\title{
The Coordination of Actors in Urban Regeneration Projects: \\ Fikirtepe, Istanbul, Turkey \\ ${ }^{*}$ Ph.D. candidate TUBA SARI HAKSEVER ${ }^{1}$ (D), Dr. CANDAN ÇINAR ÇITAK ${ }^{2}$ (D)
}

1 \& 2 Yildiz Technical University, İstanbul, Turkey

'E mail: tuubasari@gmail.com and 2E mail: candancinar@hotmail.com

\begin{tabular}{|l|}
\hline A R T I C L E I N F O: \\
\hline Article history: \\
Received 16 April 2018 \\
Accepted 23 May 2018 \\
Available online 12 October \\
2018 \\
\hline Keywords: \\
Fikirtepe; \\
Urban Regeneration; \\
Actors; \\
Partnerships
\end{tabular}

This work is licensed under a Creative Commons Attribution - NonCommercial - NoDerivs 4.0. "CC-BY-NC-ND"

\begin{abstract}
A B S T R A C T
It is necessary for urban regeneration projects to be carried out successfully in coordination with other actors. During the process of realising regeneration, many actors and stategically-given decision plays a crucial role. The ways how actors/factors are involved in the process, the relationships founded among them and investigating the methods followed during the process constitute the content of this study. The purpose of this study is to develop an approach with regard to the coordination establised between actors/factors participated during the regeneration process. This study covers the regeneration activities realised in Fikirtepe and its surrounding area, and it aims to solve the relationships among the actors during the time of planning and applications by using semi-structured technique, one of the qualitative research methods, and detailed interviews. Thanks to the data gained from the detailed interviews effectiveness of the actors has been determined. By the help of the findings obtained from Fikirtepe region, the relationships and coordination among the actors has been revealed and a new approach has been created (and suggested) concerning the effectiveness and coordination.
\end{abstract}

CONTEMPORARY URBAN AFFAIRS (2019), 3(2), 44-52.

https://doi.org/10.25034/ijcua.2018.4708

www.ijcua.com

Copyright (C) 2018 Contemporary Urban Affairs. All rights reserved.

\section{Introduction}

The concept of urban transformation have emerged with the interventions made to regenerate the areas that had collapsed both in social and economic terms. These interventions were generally in the form of implementation of projects that will contribute to the economic development of the city in housing zones, old vacant ports and industrial zones where the population decline was observed or where low income groups live under poor economical and physical conditions (Ataöv and Osmay, 2007).
In our country, the issue of urban transformation has become one of the most discussed and disputed topic with the problems of urbanization and settlement that became more visible specifically following the catastrophes in 1999 Marmara and Düzce earthquakes. (Kalağan and Çiftçi, 2012).

*Corresponding Author:

Yildiz Technical University, İstanbul, Turkey

E-mail address: tuubasari@gmail.com 
When we take a look at the path of transformation in Turkey and legislative regulations made in parallel with this we see that urban transformation is defined as 'regeneration' but with the applications seen in time, the concept varied within itself and gained new dimensions. In order to have successful outcomes in urban transformation projects, it is necessary to carry out the transformation in a coordinated manner with all stakeholders. Multiple actors from local government to centralized management, and strategic decisions have a role in the transformation process. The approaches that these actors bring in throughout the urban transformation process, their relations and partnerships are the topics explored in this study.

To analyze the relations of the actors in planning and implementation processes of the urban transformation projects carried out in the study area, Fikirtepe neighborhood and its vicinity, in-depth interviews were made using one of the qualitative research methods, the semi-structured interview technique. Multi-actor structure of the transformation projects in and around Fikirtepe makes it possible to determine urban transformation actors and the way actors are included in the process and to map the relations of these actors.

\section{Literature Review}

\subsection{Definition and Sacope of Urban Transformation}

Urban transformation is defined as comprehensive vision and action which leads to the resolution of urban problems and which seeks to bring about a lasting improvement in economic, physical, social and environmental conditions of an area that has been subject to change (Roberts and Sykes 2000). Urban area that undergoes a change may be a historical settlement, an industrial zone that lost its function or a housing zone with a lot of social and location related problems. The process that involves interventions made to economically, socially and physically resolve the problems of the region is generally referred to as "urban transformation". An urban transformation project should be based on detailed analysis of urban area's condition and effort should be made to reach an agreement with best possible engagement and cooperation of all related stakeholders in regeneration of the area (Roberts and Sykes 2000). In its UK experience, Turok (2005) associates urban transformation concept with three basic attributes.
1. It's objective is to change the nature of an area (space) and to involve the residents of the area and the other actors who have a say in the future of that area.

2. It covers various objectives and activities that intersects with basic functional responsibilities of the state depending on specific problems and potential of the area.

3. Special corporate structure of this partnership may change however it includes a structure that generally works among different stakeholders.

Urban transformation practices now have a multi-actor structure different than the previous years. It is a multi-dimensional action process where a wide range of actors act together, rather than the applications involving only the public or private sector. The tree basic elements referred above can be listed as engagement, roles and responsibilities of the public and partnerships.

\subsection{Actors, Associations And Engagements In The Urban Transformation}

Main actors involved in the urban transformation process are the public sector (centralized and local government), private sector, local residents, voluntary sector and other relevant groups (Turok 2005, Mccarthy 2005). The members of the parties of the urban transformation projects, their qualities, quantities may vary according to the quality of the transformation project, the objectives, spatial scale (approach for districts or the entire city) and may shape according to the purpose of transformation and other conditions (Turok, 2005). The term "partnership" that emerged according to the agreement reached as the result of political interests in UK draws the conclusion that a closer bond between the public and private sector and direct engagement of the local communities are required (Mccarthy, 2005).

Basically four main reasons stand out in response to the question why partnerships are required: first of all a multi-actor partnership is able to cover all aspects of the problem. This will help an efficient and fair distribution of the funding where all sectors are engaged, which makes it the second reason of the partnership approach. And third of all, vertical and horizontal engagement of all actors and organizations results with coordination of activities, funds and efforts planned for the same purpose. The fourth reason is to ensure, contrary to the top-to-bottom centralization approach, the engagement of the local community with a more extensive role, since it 
is the most affected party from the transformation. Partnerships made in the urban transformation with engagement of actors and large-scale engagement of actors that work in coordination, in an integrated way, by creating financial resources and versatile strategies in order to resolve the multi-dimensional and complex structure of urban problems play an important role in urban transformation efforts. The partnership is formed with both the organizational structure and the structure created to set policies and the actors that enable achieving the common targets. Based on this, to begin with it is necessary to define the roles of the actors that stand out in urban transformation processes (Beswick, 2001).

1) Public sector; in the transformation efforts, there is a strong public sector engagement that is managed by relevant public institutions. It is composed of local authorities (generally the representatives of various units), economic development institutions, university and colleges, representatives of regional and national administrations depending on the targets set. (Turok, 2005). Beswick (2001). Beswick suggest that the public sector, which we can define as the fundamental actor of the urban transformation process, generally leads the urban transformation projects with its supervisory and regulatory role in this partnership process. Another important function of the public sector is its ability to minimize the private sector risks by making the spatial planning of the area and generating information about political requirements in the area (Mccarthy, 2005). It is one of the most important qualities that enable the private sector to be part of the transformation process. (Özden, 2008).

2) The most important quality of the private sector and what sets it apart from the public sector is its fast operation power, design skills and professionalism, which improves the quality of urban transformation. Private sector looking for attractive opportunities to undertake urban transformation activities, usually pays attention to the physical and economic aspects of the transformation work to be carried out. The biggest contribution of private sector to urban transformation efforts is about resources and areas of expertise.

3) Local actors are individuals like residents in the area who will be directly affected from the project, members of social groups and large landowners. Turok (2005) stated that local engagement may be easier in urban transformation projects with a social aspect. In order to have a long-term transformation, the residents who live in the area must own the process and engagement of the local community must be ensured in order to win trust of the resident of the area.

4) Voluntary agencies are extensive in content and functional terms, and they are formed of civil society structures who play the role of independently handling the non-profit organizations, voluntary organizations like foundations and groups that provide funds to the society and various issues of the community and enlighten the public. (Turok, 2005).

Efficient urban transformation should be based on engagement and cooperation of numerous actors and stakeholders including local municipalities, states, national governments, landowners, investors and corporations and organizations at all levels. The idea behind the partnership is that it gathers together different actors and participants in the urban transformation process in order to create a synergic effect. In its widest sense, a partnership can be defined as a coalition of interest regulated officially, which includes actors from different sectors (public and private) and which creates a common policy and common agenda and action plan (Lang 2005).

As urban problems have a multi-dimensional and complex nature, it may help coordinating partnership activities and exceeding beyond boundaries of traditional policies (Roberts and Sykes 2000). Partnerships for urban regeneration are based on risk sharing by transferring the liability of the public sector to private sector (Davies 2004). In the urban transformation process, mainly three types of public-private sector partnership interventions are cited (Split, 2005):

Public sector managed leadership model: This model is composed of political actors and planning experts in the government and local governments. It is the model where the most authoritarian interventions take place in the urban transformation process both in operational and spatial terms.

In the public sector managed leadership model, basically the public sector provides regulative scope in the decision process, develops corporate/legal frames regarding incentives and restrictions and this way the public interest is maximized. (Alp, 2012)

It is the type of cooperation formed generally by the centralized government and local municipality, and sometimes by more than one municipality. In this model, municipalities act as entrepreneurs in regards to land services. 
Private sector does not have a very extensive role in this partnership structure it only carries out some construction works on contractual and commission basis. In short, municipalities have the total control and power in this process (Split, 2004).

Public-private sector partnership model: Publicprivate sector partnerships have emerged as a partnership model that followed the privatization policies in 1980s and found itself an execution area very rapidly. The objective of this application is to meet the housing needs by making use of public lands and taking advantage of the private sector experiences.

Public private sector partnership model is composed of actors from both sectors and semi-public representatives. It is considered as the most efficient, productive and balanced partnership model in the urban transformation process. In this type of partnership model, actors form sector-based partnership coalitions and develop regeneration strategies specific to the process. In this type of partnership models, actors form sector-based partnership coalitions and develop required regeneration strategies (Alp, 2012).

General characteristic of this type of partnership model may be defined as having the strong financial means of the private sector and the efficient function of public sector, which is guidance and regulation (as required). What sets this type of partnership apart from the others is that the cooperation with private sector continues not only on the construction phase but also throughout the operation phase and a construction and operational partnership is formed with the private sector (Split, 2004).

Private sector-managed leadership model; are composed of investors in private sector, land owners and/or semi-public representatives. This model is dissimilar to all other models in the urban transformation project as the most liberal type of strategies both on operational and spatial level are developed with this model (Alp, 2012).

\section{Case Study}

When we analyze the development of urbanization movements in Turkey, we may divide it into two periods: before and after 1950. Country's urban population that demonstrated a very slow increase until 1950 (with its own dynamics) has entered a stage of very rapid increase after this date as the result of the immigration to the cities arising from the structural transformations in the rural areas (Isik, 2005).

In Turkey, partnerships made with private sector are mostly seen in areas where the land value is high. Today, metropolitan cities where the real estate market is highly active have become the center of attraction for investors. Transformation projects carried out at areas where the land value is high, appear before us as projects that are self-financing and that can generate profit with the development rights and functions of use that are changing.

It is seen that organization among actor groups and form of relations develop and become different within the scope of unforeseen problems. Public sector that is much superior in legal terms due to the powers it possesses, requires the experience of the private sector in issues like workforce and organization and two sectors complement one another and speed up the projects. However planning and managing this relation accurately is the most important criteria for successful completion of a transformation project.

Urban transformation model organized by Ministry of Environment and Urbanization at Fikirtepe and its vicinity reveals out that the partnership structure between the private and public sector has not been fully developed yet, the project process was not planned accurately with decisions reached throughout the process, and the parties continue to find the accurate execution by trying to understand the problems encountered in implementation and reaching new decisions. Urban transformation project for Fikirtepe and its vicinity is analyzed by breaking it down to stages in order to understand which roles the public, private, and civil sector and local community actors should play in which stages of an urban transformation project.

\subsection{Site}

Fikirtepe is located at Anatolian side of Istanbul, at the center of Kadikoy country, at the point of intersection of Bosporus Bridge and D-100 highway and is very close to TEM access roads. Also it is easily accessible with public transportation. Despite its central position, we can say that it is a shanty settlement made up of unplanned structures deviating from public housing laws, its population is high, level of income and life quality is low and it is deprived of municipal services. Buildings are generally old, two and three story buildings without construction permit. Project site is defined as special project site under 1/5000 master plan 
and is declared as an urban transformation site by the Istanbul Metropolitan Municipality.

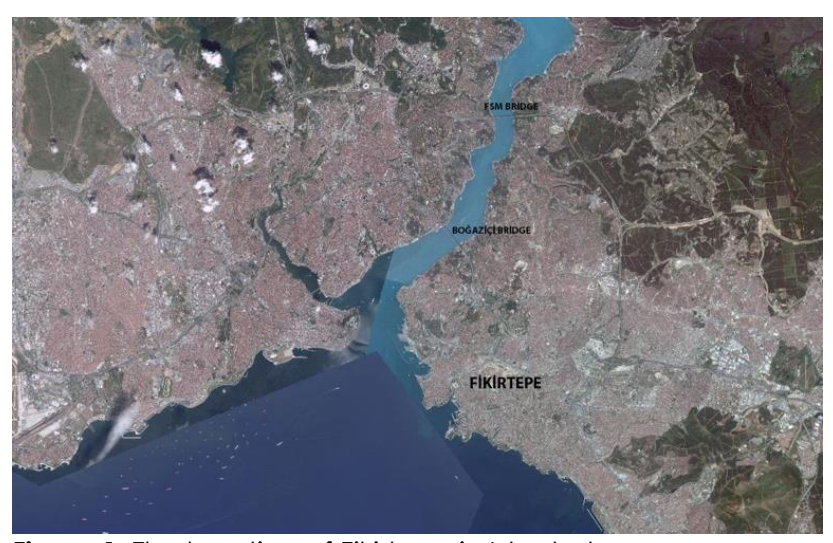

Figure 1: The location of Fikirtepe in Istanbul

Fikirtepe, elected as the study site was used as a picnic area until 1950s and after that unplanned urbanization occurred due to immigration after 1950s and in 1970s, the number of this unplanned structures increased and due to expansion of the city, the area is no in a central location and became a topic on the agenda of urban transformation process. This project has a special spot among transformation projects being carried out in Istanbul both due to its scale and the new transformation approach envisaged.

Fikirtepe area is composed of 60 city blocks. Each one of these blocks with an approximate area of 20 decare have 100-120 parcels and houses 300-400 households. With the new master plan, the structures in the form of city blocks are granted the right to use $100 \%$ additional floor area ratio, and the objective was to follow a gradual construction system and to turn the ownerships formed of very small parts into ownerships with larger parts. The plan allows individual settlements as well. However the main approach of the plan is to realize structural regeneration and transformation in line with granting extensive development rights by expanding the parcels.

It is believed that when development rights are granted to larger parcels, title holders will start to merge and eventually a structural transformation will start. As the new master plan grants the structures in the form of city blocks, the right to use $100 \%$ additional floor area ratio, a lot of construction companies tried to make agreements with the local community on flat for land basis and tried to collect parcels to form a city block. Construction companies that made an agreement with the land owners on flat for land basis, are giving the land owners flats under the new project according to square meter of their lands, and the companies also cover their rental fees until the end of the project and pay their moving in costs.

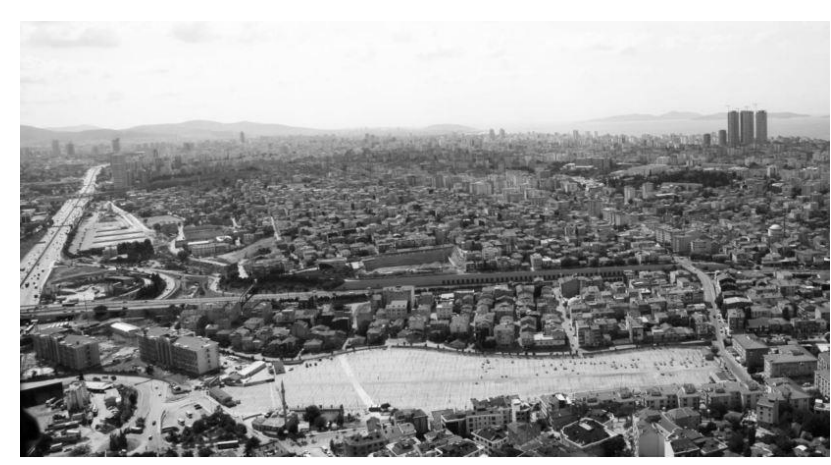

Figure 2: Current Structure in Fikirtepe

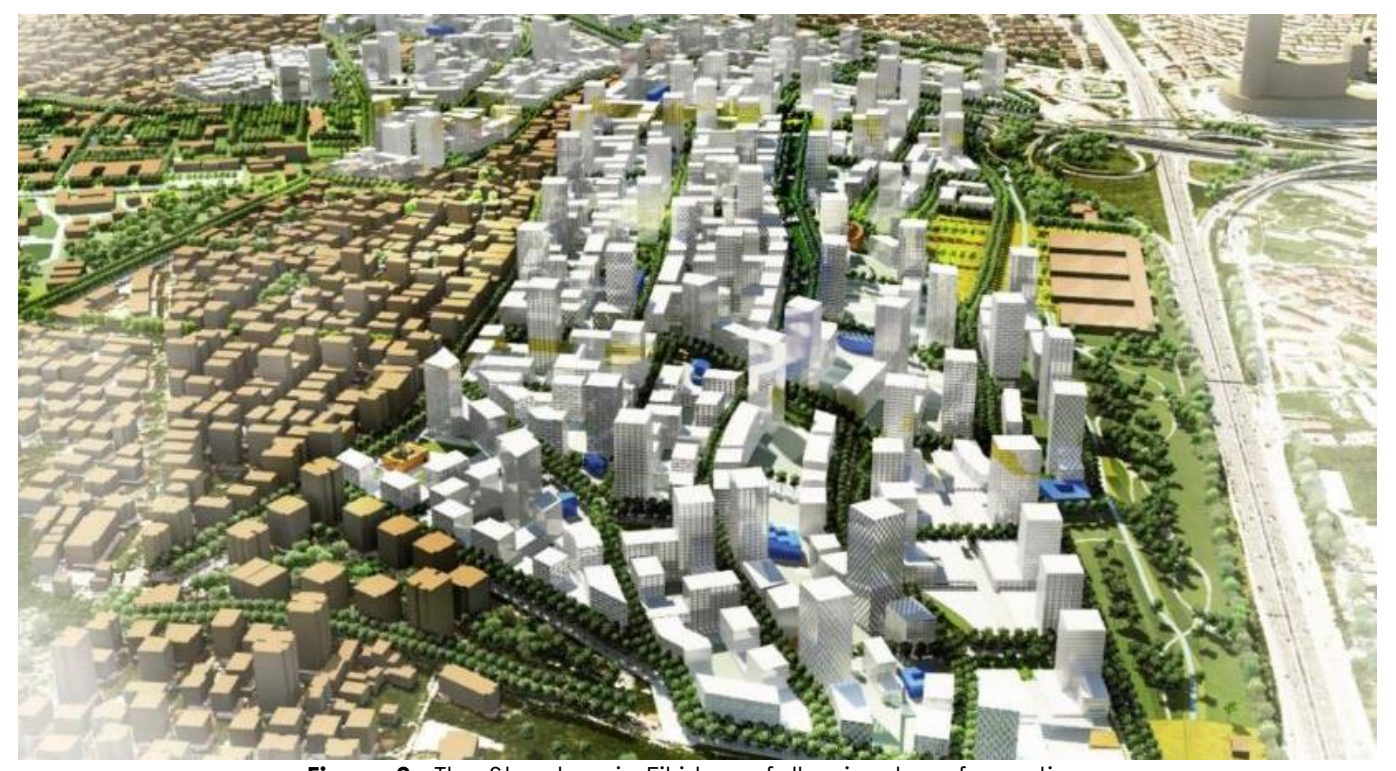

Figure 3: The Structure in Fikirtepe following transformation 
Fikirtepe and its vicinity is explored in 3 phases in terms of efficiency of the actors in the transformation process:

Table 1: Fikirtepe Urban Transformation Process

\begin{tabular}{|c|c|c|c|}
\hline Fikirtepe Urban Transformation Process & Stage & & Actors \\
\hline $\begin{array}{l}\text { 22.02.2011 Implementary Development } \\
\text { Plan }\end{array}$ & $\begin{array}{l}\text { 1st Stage } \\
2011-2013\end{array}$ & & $\begin{array}{l}\text { Isyanbul Metropolitan Municipality- } \\
\text { Kadiköy Municipality }\end{array}$ \\
\hline 28.02.2013 Cancellation Of Plan & $\begin{array}{l}\text { 2nd } \\
\text { 2013-2016 }\end{array}$ & Stage & $\begin{array}{l}\text { Ministry Of Environment And } \\
\text { Urbanization- } \\
\text { Istanbul Metropolitan Municipality }\end{array}$ \\
\hline 28.12.2016 Plan Note Amendment & $\begin{array}{l}3 r d \\
2016-2018\end{array}$ & Stage & Ministry Of Environment And Urbanization \\
\hline
\end{tabular}

1. Stage: 2011-2013; The period from the time the transformation process was initiated by Istanbul Metropolitan Municipality with the cooperation of Kadikoy Municipality until the Ministry of Environment and Urbanization declared the area as risky in 2013,

2. Stage: 2013-2016; The period until Ministry of Environment and Urbanization has been authorized as the sole authority of the new process that was initiated by Istanbul Metropolitan Municipality and Ministry of Environment and Urbanization, the public authorities for the area that had been declared as risky,

3. Stage: 2016-2018; The new process initiated with the partnership of Ministry of Environment and Urbanization and Kiptas and llbank:

\section{Methodology}

In this study, in order to accomplish the objectives of the study, semi-structured face-toface interviews were made with the actors playing a role in the urban transformation process at Fikirtepe and its vicinity. Separate forms were issued depending on the participants and actor groups interviewed. Semi-structured in-depth interviews were made with the actors at determined stages and questions and answer method is used in the process.

In this study, as the determinative feature of the qualitative researches is to discover the perspectives of the persons interviewed with, in order to explain the process that took place in the area and to understand the actors and relations, semi-structured interview technique composed of open and closed end questions was used as the data collection method. Accordingly stages and actors were determined. Afterwards in-depth interviews were analyzed with the help of these stages and titles.
To begin with, documentations regarding Fikirtepe Urban Transformation project were examined in-depth by taking into consideration the roles, responsibilities and perspectives of various stakeholders. Then in order to analyze the approach of the stakeholders to the partnerships and the transformation process, from the perspective of engagement, interviews that were semi-structured as 3 stages were made from 2016 to 2018 with 45 actors who were directly or indirectly involved in the project.

The interview questions were envisaged to underline any challenges that had been encountered to date, to discuss the ways to resolve these and to examine the strategies for facilitating engagement and partnerships of the private and public sector.

\section{Findings}

Different options of implementation for the transformation envisaged under Fikirtepe Implementary Development Plan and project implementation methods that require arrangements like increase of floor area ratio depending on parcel combinations etc. had caused the implementation process of the plan to differ from the implementation processes that were carried out until then. Many title holders in the area preferred to unite their parcels with the other title holders, instead of acting individually, in order to benefit from the highest floor area ratio granted to city blocks under the plan.

\subsection{First Stage}

Within the scope of the study regarding the transformation process, 1st stage starts upon approval of the 1/1000 scale plan by Istanbul Metropolitan Municipality in 2011. As the actor that started the Urban Transformation Process, IBB followed the strategy of monitoring the 
process rather than being involved in the process. At the beginning IBB had the authority to make the planning required to resolve the problems in the area but later it refrained from being part of the implementation process. At that stage, Istanbul Metropolitan Municipality who was the only authority under the plan, did not take part in the process and land acquisitions were made based on the contracts made between the title holders and investors.

The people interviewed stated that major challenges were experienced at this stage as the floor area ratio determined was high and as the agreements were being made between the title holders and the contractors, and they said "contractors should be inspecting the process, the local community incurs loss as the awareness raising was insufficient and that most people had to sell their land share due to extension of time,..

In the settlement process, the content of the contract concluded between the title holders and companies was configured entirely in line with their demands and no public institution had any control or guidance at this stage. Interviewed person with code $\mathrm{YHI}$ mentioned that contracts were not sufficient, and the one with code GK3 stated "we do not trust the investors,..

1st stage is carried out under the supervision of the Metropolitan and Kadikoy Municipalities, with the title of authorized institutions, and the stage ends after the plan for the process is cancelled and Ministry of Environment and Urbanization is authorized within the scope of the law no. 6306 on transformation of areas under Disaster Risk. 1st stage is mostly the period when first impressions about the transformation process in the area starts to shape.

\subsection{Second Stage}

2nd stage is in fact an important first step taken to find solutions for the challenges encountered with the plan in the 1st stage. First of all, there was a requirement at the beginning to have approval of $100 \%$ of the title holders for applications to be made on city block basis which lead to substantial problems and later with law no. 6306, 2/3 majority was considered acceptable, which paved the way for these applications. At the Preliminary Project and building permit stages, both municipalities (IBB and Kadiköy Municipality) were authorized, the time of approval processes extended, so the Ministry of
Environment and Urbanization started to manage the process as the sole actor at the beginning. Then the plan was amended and the Ministry shared this authority with Metropolitan Municipality. Due to problems like urban and social reinforcement areas not being sufficient, sustainability of reinforcement areas not being maintained as spatial distribution of reinforcement areas to be acquired from the areas to be assigned to the public, is not configured with a holistic approach, and the administration to whom the reinforcement areas will be assigned to not being clear, it was decided to increase the ratio of the reinforcement area to be assigned to the public from $20 \%$ to $25 \%$ and to assign these areas to the treasury.

Interviewed person with code CSBI states the following "the ministry was involved in the project process in order to clear the way for the process that faced a bottleneck ,, ; interviewed person with code CSB3 says "the main target is to expedite and facilitate the process ,,;

The Ministry holds the authority for the amendment of the plan and building permits and has granted the authority to approve the project to Istanbul Metropolitan Municipality. As officially Kadıköy Municipality is no longer part of the transformation works. Another important step taken to expedite the agreements was the Urgent Expropriation Decree enforced by the Ministry. This way the state would have the authority for expropriation in respect of the city blocks on which an agreement could not be reached and the process will progress more rapidly. However the expropriation process lasted much longer than estimated so shortly after it was decided to annul the decree for expropriation.

Another important development in the process, in respect of organization among the actors, was the formation of Fikirtepe Platform by 17 members of Fikirtepe Urban Transformation Association that continue their Urban Transformation studies in Fikirtepe, with the purpose of ensuring secure and regular housing in the area. Platform Member with code ÖS1 states his opinion;

"Urban transformation at Fikirtepe gained outstanding speed with the support of Ministry of Environment and Urbanization".

One of the most important problems in this process was the lack of a reconciliation platform where actors could meet. That's why contractors' platform has become very efficient in determining the common problems 
of the private sector and communicating the problems to relevant authorities.

IBB and Ministry of Environment and Urbanization acted unofficially as problem resolution units. Title holders and contractors participated in meetings at Metropolitan Municipality and Ministry premises from time to time in order to both explain their problems and to reach a consensus.

Another important development in terms of expediting the process was the omnibus bill enacted in 2016. By including the provision permitting sales on city block basis, urgent expropriation cases were dropped and share sales started.

Companies informed the Ministry of Environment and Urbanization about the agreement ratio in the city blocks they are interested in and the Ministry evaluates whether these city blocks are subject to sale. In case an agreement of $2 / 3$ is reached, the rights of the remaining $1 / 3$ is sold to the other residents of the city block. This omnibus bill paved the way for permitting sale of the rights of $1 / 3$ rd of the title holders, which was an important development that expedited the process.

However since city block based agreements took long and evacuations on area basis were made and as the contractors had to pay rent for a long term as public institutions could not reach a settlement among themselves which caused delay of required documents, they faced financial difficulties. At this stage some companies declared bankruptcy and tried to reach settlements with foreign partners. At this point it was highlighted that as a right granted under the law "rent fees should be paid by the public,...

\subsection{Third Stage}

One of the most important phase of urban transformation process of Fikirtepe and its vicinity is the addition of the decision "preliminary project approval will be cancelled and implementation will be done only according to the architectural project to be approved by the Ministry of Environment and Urbanization" with the amendment of the plan in 2016. With this decision, Istanbul Metropolitan Municipality that was included in the transformation process as required by its authority, is no longer an actor in the process as required by the plan note. And this amendment of the plan is the start of the 3rd stage. The interviewed person with code CS4 emphasizes that; "this amendment was made to achieve progress in the process".

Likewise interviewed person with code OS11 states that "The Ministry should be part of the transformation process exercising its control authority";

Ministry of Environment and Urbanization continues its activities to complete the transformation in the area rapidly by providing interim solutions, while negotiating for partnership with companies in the area that are facing financial difficulties. To avoid suffering of the public due to projects that could not have been completed by the companies because of the financial difficulties they face, the Bank of Provinces running under the Ministry and Kiptaş, an affiliate of Istanbul Metropolitan Municipality, formed a partnership to complete the 2 projects that were suspended. In this partnership protocol signed by Ministry of Environment and Urbanization, the Bank of Provinces and Kiptas, the Bank of Provinces is responsible of the financing and Kiptas is responsible for the construction.

\section{Discussions}

Urban transformation process being implemented at Fikirtepe area chosen as the site for this study was explored to uncover the role of the actors in the transformation process and engagement among actors and partnerships. The findings suggest that transformation works should be carried out in coordination with all stakeholders in order to have a successful outcome and that a more efficient and productive relation is required between the private and public sector (Roberts and Sykes, 2000). It is specifically anticipated that the effects of partnership structures of the actors will become evident in the long term (Garcia, 2004).

In order to have a feasible urban transformation, long term planning should be made and partnership and cooperation between actors should be ensured by taking into consideration all the transformation factors. Solid coordination and strong communication network among the parties is required to realize the partnership model, it should not be just an economic agreement. In the study exploring the urban transformation project for Fikirtepe and its vicinity, some of the major issues that arise as problems in the urban transformation processes in our country are elaborated. These are; 
The members of the parties of the urban transformation projects, their qualities, quantities may vary according to the quality of the transformation project, the objectives, spatial scale (approach for districts or the entire city) and may shape according to the purpose of transformation and other conditions (Turok, 2005). Actors and their roles in the transformation area should be determined. Authorities and responsibilities in the management and organization of urban transformation area should be defined clearly.

The public sector, the actor initiating the transformation projects, needs to take the leadership role throughout the process. The authority and task sharing among public institutions must be clarified as a priority. It is considered that the public sector, which we may describe as the main actor of the urban transformation process, needs to take on supervisory and regulatory role in the partnership process and in general the leadership role in the urban transformation projects (Split, 2005). Public sector should be able to minimize the private sector risks by generation of knowledge regarding spatial planning and political requirements in the area (Mccarthy, 2005).

If the local community does not clearly understand the methods and reasons of transformation, the expectations of the target group will vary and this will lead to loss of trust. The project scenario should be developed together with the residents of the area and the community must take an active role in the project and its implementation.

It is observed that organization among actor groups and relation patterns listed under unforeseen problems are developing and changing. Public sector that is much superior in legal terms due to the powers it possesses, requires the experience of the private sector in issues like workforce and organization and two sectors complement one another and speed up the projects. However planning and managing this relation accurately is the most important criteria for successful completion of a transformation project.

Public wants to be a part of the negotiation process among title holders and contractors until an agreement is reached between the parties (contract based) just like in Fikirtepe case. However it's role should be to balance the relations between actors and to control the transformation project. Government should protect the rights of the actors, encourage engagement of various organizations that will make significant contributions to urban transformation and should determine the responsibilities. Multi-actor partnership structure has the ability to cover all aspects of an urban problem.

As Scharpf (1997) says each actor in the urban transformation process has its own strategy and style. Each actor is in fact an institution on its own. However since the result of the selected strategy depends on the strategies of the other, the objectives are interdependent. Also we should not forget that people always act in the interest of their own so it is not possible to explain the interactions purely objectively. (Scharpf, 1997). Actor groups that can organize take decisions much easily. The size of the group show that people are controlled by the group they are part of and their actions are limited accordingly. (Douglas, 2007).

\section{Conclusions}

Models that involve all actors in the planning and implementation process are required to figure out the multi-dimensional and complex structure of urban transformation projects. These models should be formed under the leadership of the public sector and engagement of all relevant actors in the transformation process should be ensured. The primary role of the public sector should be to guide, supervise and regulate.

In Turkey, a multi-actor partnership approach should be adopted with participation of private sector, voluntary sector and local community along with the public sector. As actors take more roles in urban transformation projects, economic, social and managerial aspects will develop. To incorporate the private sector in urban transformation projects, some of the incentives expected by the private sector should be given and attractive terms should be provided. Local community should be incorporated in the transformation process at the planning phase and must be informed about updates at each stage of the process and their engagement should be ensured.

Urban transformation projects should be clearly configured and planned right from the start and partnership structures that will follow-up the changing conditions and keep these under control needs to be developed.

\section{Acknowledgements}

This research did not receive any specific grant from funding agencies in the public, commercial, or not-for-profit sectors. 


\section{Conflict of interests}

The authors declare no conflict of interest.

\section{References}

Alp, J. (2012). Urban projects in the context of organizing capacity Istanbul Kartal example, (Doctoral Dissertation), Mimar Sinan Fine Arts University, İstanbul. Retrieved from:

https://tez.yok.gov.tr/UlusalTezMerkezi/3285 16

Ataöv, O. and Osmay, S. (2007). Methodological approach to urban transformation in Turkey, Middle East Technical University Journal of the Faculty of Architecture, 2007/2, (24:2), 57-82. http://jfa.arch.metu.edu.tr/archive/02585316/2007/cilt24/sayi_2/57-82.pdf

Beswick, C. Ann (2001). Public-Private Partnerships In Urban Regeneration: The Case of London Docklands, (Master Dissertation), Calgary University Faculty of Enviromental Design, Calgary. https://scholar.google.com.tr/scholar?q=Pu blicPrivate+Partnerships+In+Urban+Regener ation:+The+Case+of+London+Docklands\&h I=tr\&as_sdt=0\&as_vis $=1$ \&oi=scholart

Davies, Jonathan (2004). Conjuncture or disjuncture? : An institutionalist analysis of local regeneration partnerships in the UK. International Journal of Urban and Regional Research, Vol.28 (No.3). pp. 570585. $\quad$ http://dx.doi.org/10.1111/j.03091317.2004.00536.x

Douglas, M. (1966). Purity and danger: an analysis of the concepts of pollution and taboo, London: Routledge. https://monoskop.org/images/7/7d/Dougla s_Mary_Purity_and_Danger_An_Analysis_of_ Concepts_of_Pollution_and_Taboo_2001.pd $f$

Garcia, B. (2004). Cultural policy and urban regeneration in Western European cities: Lessons from experience, prospects for the future. Local Economy, 19(4), pp. 312-326. Retrieved from https://doi.org/10.1080/02690940420002868 28

Isik, S. (2005). Urbanization and Urbanization Model in Turkey. Aegean Geographical Journal: 14, s. 57-71. Retrieved from http://dergipark.gov.tr/download/articlefile/56792

Kalağan, G., Çiftçi, S. (2012). Public-Private Sector Cooperation in Urban Space Reflections: Urban Transformation Example and New Actors, Journal of Social and
Humanities, Volume 4, No 2, 2012 ISSN:13098012 Retrieved from http://dergipark.gov.tr/sobiadsbd/issue/113 $54 / 135702$

Lang, T. (2005). Insights in the British Debate about Urban Decline and Urban Regeneration, Working Paper, Erkner, Leibniz-Institute for Regional Development and Structural Planning. Retrieved from http://www.irsnet.de/download/wp_insights.pdf

Mccarthy, J., (2005). Kentsel Dönüşümde Ortaklık Pratiği [Partnership Practice in Urban Transformation], International Symposium on Urban Transformation, D. Özdemir, P. Özden, S. Turgut, International Symposium on Urban Transformation, 99107. Küçük Çekmece Municipality Publications, Istanbul 2004 proceedings book, İstanbul

http://dergipark.gov.tr/tojdac/issue/34578/ 381850

Ozden, P. P. (2008). Urban Renewal. Istanbul, Turkey: Imge

http://www.onuracar.com/wpcontent/uploads/2014/02/5320_odev.pdf

Roberts P.W., \& Sykes, H. (2000). Urban Regeneration. A Handbook. London. SAGE. Retrieved from http://dx.doi.org/10.4135/9781446219980

Scharpf, F (1997). Games Real Actors Play. Actor-Centered Institutionalism in Policy Research. Oxford: Westview Press. Retrieved from https://epdf.tips/queve/games-real-actorsplay-actor-centered-institutionalism-inpolicy-research-theore.html

Spit, T. (2004). Public-private partnerships: a tense relationship in the context of urban restructuring: Dutch experience, D. Özdemir, P. Özden, S. Turgut, International Symposium on Urban Transformation, 108116. Küçük Çekmece Municipality Publications, Istanbul 2004 proceedings book, istanbul. http://www.academia.edu/1367335/Kentse I D\%C3\%B6n\%C3\%BC\%C5\%9F\%C3\%BCmde Kamu_\%C3\%96zel_Ortakl\%C4\%Bl klar\%C4\% B1_ve_\%C3\%96zel_Giri\%C5\%9Fimin_D\%C3\% B6n\%C3\%BC\%C5\%9F\%C3\%BCmdeki_Varl\%C 4\%B1\%C4\%9F\%C4\%B1_Konya_\%C3\%96rne\% $\mathrm{C} 4 \% 9 \mathrm{Fi}$

Turok, I., (2005). Cities, Competition and Competitiveness: Identifying New Connections, Changing Cities. Retrieved from http://25-43. doi:10.1007/978-023021203-9_2 